\title{
POTENSI KANDUNGAN ANTIOKSIDAN RUMPUT KEBAR (Biophytum Petersianum Klotzsch) TERHADAP APOPTOSIS DAN GAMBARAN HISTOPATOLOGIS TESTIS PADA MENCIT (MUS MUSCULUS) YANG DIPAPAR 2,3,7,8-Tetrachlorodibenzo-p-dioxin
}

\section{ANTIOXIDANT PROPERTIES OF Biophytum Petersianum Klotzsch TO APOPTOSIS AND HISTOPATHOLOGY CHANGES OF TESTES IN 2,3,7,8-Tetrachlorodibenzo-p-dioxin EXPOSED MALE MICE}

\author{
Dewita 1), Widjiati 2), Rimayanti 2), Tri W. Suprayogi 2), Mas'ud 2), Hani Plumeriastuti 2) \\ 1) Mahasiswa, 2) Dosen \\ Fakultas Kedokteran Hewan Universitas Airlangga \\ Kampus C UNAIR, Jl. Mulyorejo-Surabaya 60115 \\ Telp. 031-5992785, Fax. 031-5993015 \\ Email: jbmvunair@gmail.com
}

\begin{abstract}
2,3,7,8-Tetrachlorodibenzo-p-dioxin (TCDD) is the most toxic compound in the dioxin group. This compound is a pollutant for the environment and very harmful to human health and enter the body through the mucous membranes in the mouth and the respiratory tract and can be transmitted through the placenta and lactation. The aim of this study was to know the antioxidant potency of to resolve reproduction disturbance caused by TCDD exposure.

Thirty Balb/C male mice were divided into five different groups, the negative control group, a positive control group exposed to TCDD at a dose of $7 \mu \mathrm{g} / \mathrm{kg} \mathrm{BW}, \mathrm{P} 1$ group of groups exposed to TCDD doses of $7 \mathrm{\mu g} / \mathrm{kg}$ BW and given Biophytum petersianum extract $0.05 \mathrm{mg} / \mathrm{gBB} /$ day, group P2 group exposed to TCDD doses of $7 \mu \mathrm{g} / \mathrm{kgBW}$ and given $0.080 \mathrm{mg} / \mathrm{gBB} /$ day, and group P3 were exposed to TCDD dose of $7 \mu \mathrm{g} / \mathrm{kgBB}$ and given the extract of Biophytum petersianum $0.135 \mathrm{mg} / \mathrm{gBB} /$ day during day 2 to day 55. On the 56th day the mice were sacrificed and apoptotic examination and spermatogenic cell histopathological features were performed on the testis. The results showed that: P2 $(0,433 \pm 0,497 ; \mathrm{p}<0,05)$ and P3 $(0,200 \pm 0,000$ $\mathrm{p}<0,05)$ groups were the most effective group in decreasing spermatogenic cell apoptosis compared to positive control group $(2,933 \pm 1,5832 \mathrm{p}<0,05)$. The Johnsen score result showed that P2 $(9,400 \pm 0,420)$ and P3 $(9,800 \pm 0,253)$ groups improving the histopathologic picture of spermatogenic cells in seminiferous tubules compared to positive control group $(7,20 \pm 0,400)$ $p<0,05$. Conclusion of this study were Biophytum petersianum is effective to solve reproduction disturbances caused by exposure of TCDD and the P3 group is the most effective group.
\end{abstract}

Key words: 2,3,7,8-Tetrachlorodibenzo-p-dioxin, apoptosis, Biophytum petersianum, spermatogenic cells

\section{PENDAHULUAN}

Senyawa

2,3,7,8-Tetrachloro dibenzo- $p$-dioxin merupakan polutan bagi lingkungan dan berbahaya bagi kesehatan manusia dan satwa liar serta menjadi masalah utama dalam dekade ini memiliki berbagai efek toksik seperti aswasting syndrome, karsinogenesis, imunosupresi, dan bersifat teratogenik (Takeda et al., 2014). 2,3,7,8Tetrachlorodibenzo- $p$-dioxin pada tahun
1997 telah dikategorikan sebagai karsinogenik pada manusia oleh International Agency for Research on Cancer (Pilsner et al., 2017).

Senyawa 2,3,7,8-Tetrachloro dibenzo-p dioxin dihasilkan dari pembakaran limbah, pemutihan kertas, peleburan logam, proses kimiawi pembuatan insektisida, herbisida, fungisida (Shibamoto et al., 2007; Dhanabalan dan Mathur, 2009) serta 
dapat terakumulasi di manusia umumnya melalui produk olahan susu, produk hasil bidang perunggasan, daging, ikan, telur dan makanan yang mengandung lemak serta dapat juga ditransmisikan melalui plasenta serta laktasi. Senyawa ini dapat bertahan dalam tubuh selama tujuh hingga sembilan tahun dan juga bersifat lipofilik, metabolismenya lambat serta eksresi yang lambat (Aylward et al., 2004).

Menurut penelitian yang dilakukan oleh Gies et al., (2007) menemukan bahwa bayi dan anak-anak umumnya terpapar komponen ini melalui pangan. Lebih lanjutnya bayi yang masih menyusui merupakan kelompok yang paling banyak terpapar yaitu hamper mencapai 50 kali lipat dari standar aman yang ditetapkan oleh Enviromental Protection Agency (EPA, 2012).

Studi epidemiologis terkait dengan golongan dioksin pada Flemish yang tinggal di daerah limbah incinerator menunjukkan adanya kelambatan pada perkembangan pubertas. Studi yang sama menunjukkan adanya peningkatan abnormalitas morfologi sperma, penurunan motilitas, dan penurunan kemamapuan penetrasi oosit ditemukan pada pria yang terpapar golongan dioksin selama periode perinatal dan laktasi (Guo et al., 2004) serta pada pria yang terpapar di waktu dewasa.

Secara etis tidak mungkin melakukan uji coba paparan dioksin pada manusia oleh karena itu diperlukan model hewan coba untuk memprediksi efek negatif yang mungkin ditimbulkan. Studi menggunakan TCDD menunjukkan bahwa paparan TCDD pada masa embriogenik dapat merusak berbagai fungsi neuron terkait seks spesifik, termasuk juga memori dan daya kembang serta peran fungsi endokrin (Widholm et al., 2003; Wormley et al., 2004). Berbagai fungsi ini seperti identitas gender, respon terhadap stress, dan kelainan neurodegeneratif dapat tampak secara berbeda pada jantan dan betina (Zaidi, 2010).

Rumput kebar adalah tanaman obat yang banyak ditemukan di negara tropis dan negara subtropis di Afrika dan Asia adalah rumput kebar (Biophytum petersianum Klotzsch; sinonim Biophytum umbraculum Welw.) (Gronhaug et al., 2008; Lye et al., 2008). Tumbuhan ini secara tradisional digunakan sebagai terapi pada berbagai penyakit yang berhubungan dengan sistem imun (Inngjerdingen et al., 2008). Penelitian yang dilakukan oleh Srinivasan et al., 2017 mengevaluasi aktivitas antioksidan dari tumbuhan ini secara in vitro menunjukkan bahwa tanaman ini memiliki kemampuan antioksidan yang baik dalam uji Free Radical Scavenging (DPPH) dan Ferric Reducing Ability (FRAP).

Oleh karena itu perlu dibuktikan efektivitas penggunaan antioksidan dari ekstrak rumput kebar sebagai proteksi terhadap efek negatif yang disebabkan oleh paparan TCDD, sehingga dapat diungkapkan potensi efek ameliorasi tumbuhan tersebut pada mencit jantan yang diberi paparan TCDD.

\section{MATERI DAN METODE}

Penelitian ini dilaksanakan di Laboratorium Hewan Coba Fakultas Kedokteran Hewan Universitas Airlangga mulai dari 6 Februari- 15 April 2017. Tiga puluh mencit jantan Balb/C didapatkan dari LPPT Universitas Gajah Mada dan dibagi menjadi lima kelompok dengan berat badan 30-35 gram dan berusia empat bulan. Pemeriksaan apoptosis dan histopatologi testis dilakukan di departemen Patologi Fakultas Kedokteran Hewan Universitas Airlangga. 
Dosis

Dosis TCDD yang digunakan
yaitu $7 \mu \mathrm{g} / \mathrm{kgBB}$ single dose dan
diberikan secara intraperitoneal
sebanyak 0,1ml pada hari ke-1 (Jong et
al., 2007). Dosis Biophytum petersianum
extract yang digunakan adalah ekstrak
ethanol $70 \%$ yang telah dikonversikan
ke volume sebesar 0,1ml/10g BB dalam
larutan CMCNa 0,5\% dengan dosis
$0,045 \mathrm{mg} / \mathrm{g} \mathrm{BB}$, dan $0,080 \mathrm{mg} / \mathrm{g} \mathrm{BB}$, dan
0,135mg/g BB per hari secara per oral
pada hari ke-2 hingga hari ke-55
(Sadsoeitoebon, 2005).

\section{PROSEDUR PENELITIAN}

Prosedur Pemberian TCDD

TCDD diberikan secara parenteral (intraperitoneal) dengan dosis $7 \mu \mathrm{g} / \mathrm{kgBB}$ single dose pada hari ke-1. Hewan coba ditempatkan dalam kandang pemeliharan sampai penelitian selesai dilakukan. Kelompok P1, P2 dan P3 diberikan ekstrak rumput kebar pada hari ke-2 hingga hari ke-55.

Dosis paparan TCDD berdasarkan penelitian yang dilakukan oleh Jong et al., 2007 yang membuktikan bahwa dosis tersebut telah mampu menurunkan berat testis, score Johnsen, ukuran tubulus seminiferus, persentase tubulus yang terdapat sperma, jumlah sperma, dan jumlah sel sertoli secara signifikan.

\section{Prosedur Pembuatan dan Pemberian Ekstrak Rumput Kebar}

Rumput kebar yang digunakan dalam penelitian ini diperoleh dari Kecamatan Kebar Kabupaten Manokwari, Provinsi Papua Barat. Mencit pada kelompok P1, P2 dan P3 diberi ekstrak ethanol rumput kebar dengan volume $0,1 \mathrm{ml} /$ ekor dengan dosis 0,045 mg/gBB/hari, 0,080 mg /gBB/hari, dan 0,135 mg /gBB/hari. Ketiga dosis tersebut diperoleh berdasarkan penelitian yang dilakukan oleh Satsoeitoeboen di tahun 2005.
Ekstrak rumput kebar diberikan dalam larutan $\mathrm{CMCNa} 0,5 \%$ dengan pengenceran $0,1 \mathrm{ml} / 10 \mathrm{~g} \mathrm{BB}$.

\section{Pengamatan Apoptosis dengan Metode TUNEL}

Tumor TACS in situ TUNEL-based Kit TA5411 digunakan untuk mendeteksi apoptosis pada potongan blok paraffin setebal $3 \mu \mathrm{m}$. Potongan jaringan dari blok paraffin ditempatkan pada slide, kemudian dideparafinasasi dengan xylol (PA) dua kali masingmasing selama 3 menit, direhidrasi dengan alkohol bertingkat (absolut 95\%, $90 \%, 80 \%, 70 \%$ ) dan air masing-masing selama 5 menit. Slide dicuci dengan aquabidest steril. Ditambahkan $50 \mathrm{ul}$ tunnel label mix dengan TdT. Inkubasi 30 menit pada suhu $37^{\circ} \mathrm{C}$ dalam chamber. Slide dicuci $3 x$ dengan PBS. Inkubasi slide dengan RNA ( $5 \mathrm{ug} / \mathrm{ml}$ ) solution 30 menit pada suhu $37^{\circ} \mathrm{C}$. Slide dicuci 3 kali dengan PBS. Inkubasi slide dengan propidium iodide $(1 \mathrm{ul} / \mathrm{ml})$. Cuci dengan PBS 3 kali. Ditutup dengan cover slide $18 \mathrm{~mm}$ dan imumount.

Perhitungan apoptosis sel spermatogenik pada tubulus seminiferus yang mengekspresikan Apoptosis dilakukan dengan metode modifikasi semikuantitatif Indeks Skala Remmele (IRS) yang merupakan hasil perkalian antara skor persentase sel positif (A) dengan skor intensitas warna (B) (Nowak et al., 2007).

Perubahan histopatologi pada sel spermatogenik di tubulus seminiferus testis diamati dengan menggunakan mikroskop dengan pembesaran 400 kali pada lima lapang pandang yang berbeda dengan menggunakan kriteria Johnsen score dengan skala 1-10.

\section{ANALISIS DATA}

Data yang diperoleh kemudian dianalisis menggunakan uji non parametrik. Uji non parametrik dilakukan menggunakan uji KruskalWallis dilanjutkan dengan uji Mann- 
Whitney untuk mengetahui kelompok manakah yang memiliki perbedaan paling signifikan di antara kelompok lainnya.

\section{HASIL DAN PEMBAHASAN}

Berdasarkan hasil perhitungan skoring terhadap sel spermatogenik pada tubulus seminiferus yang mengekspresikan Apoptosis dengan metode modifikasi semikuantitatif Indeks Skala Remmele (IRS) yang merupakan hasil perkalian antara skor persentase sel positif (A) dengan skor intensitas warna (B) (Nowak et al., 2007).

\begin{tabular}{|l|l|l|l|}
\hline PARAMETER & KEL. & KEL. & \multicolumn{1}{l|}{ SIG. } \\
\hline \multirow{2}{*}{ APOPTOSIS } & K- & K+ & $0,004^{*}$ \\
& & P1 & $0,005^{*}$ \\
& & P2 & 0,155 \\
& & P3 & 0,248 \\
\hline & K+ & P1 & 0,077 \\
& & P2 & $0,006^{*}$ \\
& & P3 & $0,002^{*}$ \\
\hline & P1 & P2 & $0,023^{*}$ \\
& & P3 & $0,002^{*}$ \\
\hline & P2 & P3 & 0,252 \\
\hline
\end{tabular}

Tabel 1. Hasil uji Mann Whitney ekspresi Apoptosis sel spermatogenik pada tubulus seminiferus mencit yang diberi ekstrak rumput kebar pada mencit jantan yang dipapar TCDD *. Signifikan pada $\mathrm{p}<0,05$

Berdasarkan tabel diatas dapat terlihat bahwa pada kelompok kontrol negatif berbeda nyata jika dibandingkan dengan kelompok kontrol positif $(\mathrm{K}+)$ dan P2 $(\mathrm{p}<0,05)$ namun tidak berbeda nyata dengan kelompok P2 dan P3 ( $\mathrm{p}>0,05)$. Sedangkan kelompok kontrol positif $(\mathrm{K}+)$ berbeda nyata dengan kelompok P2 dan kelompok P3 ( $<<0,05)$, namun tidak berbeda nyata dengan kelompok P1 $(p<0,05)$. Kelompok P1 terlihat berbeda nyata dengan kelompok
P2 dan P3 $(p<0,05)$, namun terlihat bahwa tidak ada perbedaan yang nyata antara kelompok P2 dan P3 ( $p>0,05)$. Berdasarkan hasil tersebut dapat menunjukkan bahwa pemberian ekstrak rumput kebar pada mencit yang dipapar TCDD dapat menurunkan apoptosis pada sel spermatogenik di tubulus seminiferus. Namun bila dilihat berdasarkan dosis, terlihat bahwa dosis pada kelompok P2 dan P3 yang menunjukkan pengaruh nyata dapat menurunkan indeks Apoptosis pada sel spermatogenik di tubulus seminiferus.

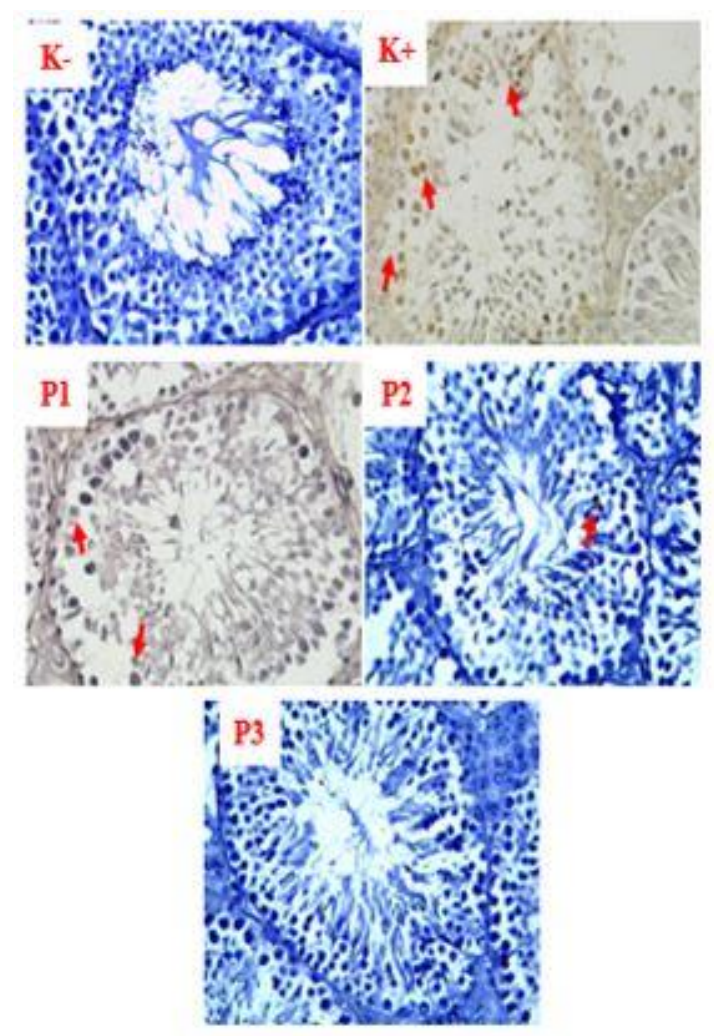

Gambar 5.1. Ekspresi Apoptosis pada tubulus seminiferus mencit (Mus musculus) pada tiap kelompok perlakuan. Keterangan tanda panah merah menunjukkan adanya ekspresi Apoptosis pada perlakuan. (Nikon Eclipse E-100; perbesaran 400x) 


\section{Gambaran Histopatologis Sel Spermatogenik}

Berdasarkan hasil perhitungan
skoring terhadap $\begin{array}{r}\text { gambaran } \\ \text { histopatologis sel spermatogenik }\end{array}$
dengan metode Johnsen score. Data
hasil perhitungan dari semua perlakuan
kemudian dianalisis dengan uji Kruskal-
Wallis dan didapatkan hasil yang
berbeda nyata $(\mathrm{p}<0,05)$ kemudian
dilanjutkan dengan uji Mann Whitney
antar dua kelompok perlakuan masing-
masing.

Tabel 5.2. Hasil uji Mann Whitney gambaran histopatologis sel spermatogenik pada tubulus seminiferus mencit yang diberi ekstrak rumput kebar pada mencit jantan yang dipapar TCDD *. Signifikan pada $\mathrm{p}<0,05$

\begin{tabular}{|c|l|l|l|}
\hline PARAMETER & KEL. & $\begin{array}{l}\text { KEL. } \\
\text { BANDING }\end{array}$ & \multicolumn{1}{l|}{ SIG. } \\
\hline GAMBARAN & K- & K+ & $0,004^{*}$ \\
HISTOPATOLOGIS & & P1 & $0,022^{*}$ \\
& & P2 & 0,070 \\
& & P3 & 0,866 \\
\cline { 2 - 4 } & K+ & P1 & $0,004 *$ \\
& & P2 & $0,004 *$ \\
& & P3 & $0,003 *$ \\
\cline { 2 - 4 } & P1 & P2 & 0,683 \\
& & P3 & $0,034^{*}$ \\
\cline { 2 - 4 } & P2 & P3 & 0,073 \\
\hline
\end{tabular}

Berdasarkan tabel diatas dapat terlihat bahwa pada kelompok kontrol negatif berbeda nyata dengan kelompok kontrol positif $(\mathrm{K}+)$ dan P1 $(\mathrm{p}<0,05)$, namun tidak berbeda nyata dengan kelompok P2 dan P3 ( $>00,05)$. Sedangkan pada kelompok $\mathrm{K}+$ terlihat berbeda nyata dengan kelompok P1, P2, dan P3 $(\mathrm{p}<0,05)$. Pada kelompok P1 terlihat berbeda nyata dengan kelompok P3 $(\mathrm{p}<0,05)$ namun tidak berbeda nyata dengan kelompok P2 ( $>>0,05)$. Begitu juga dengan kelompok P2 tidak berbeda nyata dengan kelompok P3.
Berdasarkan hasil tersebut dapat menunjukkan bahwa pemberian ekstrak rumput kebar pada mencit yang dipapar TCDD dapat memperbaiki gambaran histopatologis sel spermatogenik di tubulus seminiferus. Namun bila dilihat berdasarkan dosis, terlihat bahwa dosis pada kelompok P2 dan P3 yang menunjukkan pengaruh nyata dapat memperbaiki gambaran histopatologis sel spermatogenik di tubulus seminiferus.

Jika ditinjau menurut dosis, kelompok P1 yang diberi ekstrak rumput kebar dengan dosis 0,045mg/gBB/hari memiliki perbedaan yang nyata jika dibandingkan dengan kelompok kontrol positif, namun juga berbeda nyata dengan kelompok kontrol negatif. Hasil penelitian ini menunjukkan bahwa pemberian ekstrak rumput kebar memberikan pengaruh yang nyata dalam memperbaiki gambaran histopatologi spermatogenik.
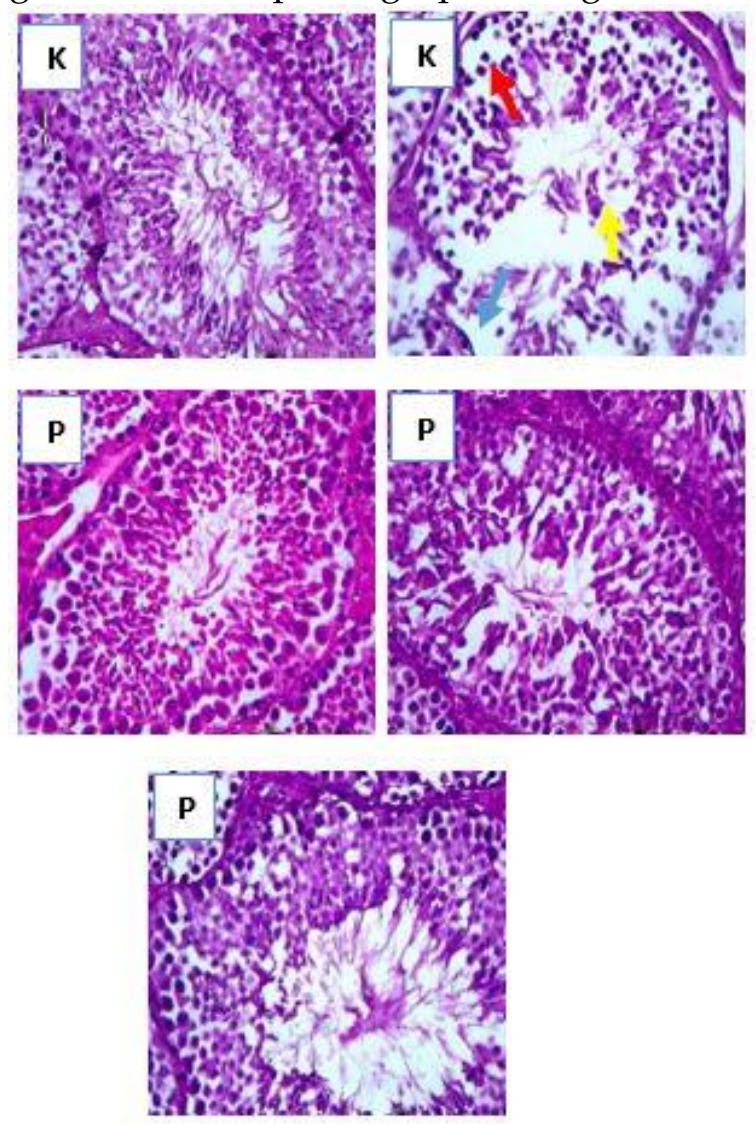
Gambar 2. Gambaran histopatologis sel spermatogenik tubulus seminiferus testis mencit (Mus musculus) pada tiap perlakuan. Keterangan: Panah biru menunjukkan kerusakan epitel basalis, panah merah menunjukkan penurunan ketebalan epitel, dan panah kuning menunjukkan penurunan jumlah spermatozoa (Pewarnaan HE: Perbesaran 400x).

Paparan berbagai kontaminan lingkungan diketahui menyebabkan berbeagai efek negatif pada reproduksi jantan pada manusia maupun hewan coba, salah satu diantaranya yaitu TCDD (Mendiola et al., 2009). Senyawa TCDD yang merupakan golongan dioksin, termasuk dalam senyawa organoklorin yang terbentuk sebagai produk yang berasal dari hasil proses industri maupun hasil pembakaran yang terakumulasi dalam rantai makanan dan akan menjadi sangat toksik jika berikatan dengan reseptor AhR. Senyawa ini juga menyebabkan gangguan pada aktivitas hormonal sehingga mengakibatkan penurunan pada kualitas spermatozoa (Sonne et al., 2009).

Organ reproduksi jantan nerupakan target yang sangat sensitif terhadap TCDD (Gray et al., 1997). Studi yang dilakukan oleh Dhanabalan et al., 2010 juga menunjukkan bahwa pemberian TCDD pada tikus menyebabkan penurunan berat dari organ aksesoris jantan seperti epididimis, vesikula seminalis, dan prostat secara signifikan, dan disimpulkan bahwa penurunan berat ini disebabkan oleh penurunan kadar testosteron pada darah. Penurunan sperma epididimis, motilitas dan viabilitas sperma juga dilaporkan dalam penelitian ini. Apoptosis yang disebabkan oleh TCDD dimediasi oleh pelepasan Bax dan Sitokrom C dari mitokondria yang mengalami disfungsi (Chen et al., 2010).

Mitokondria merupakan produsen energi seluler utama dan terlibat pada homeostasis $\mathrm{Ca}^{2+}$, sebagai mediator pembentukan radikal bebas dan apoptosis, dan juga merupakan target potensial dari obat, dan kontaminan lingkungan (Pereira et al., 2009). Studi yang dilakukan untuk mengetahui potensi toksisitas dan karsinogenik dari TCDD yang berfokus pada disfungsi mitokondrial menunjukkan bahwa terjadinya penurunan mitochondrial membrane potential (MMP) (Aly dan Domènech, 2009), peningkatan produksi Reactive Oxygen Species (ROS) (Shertzer et al., 2006), perusakan copy number mitokondrial DNA (Chen et al., 2010), dan penurunan ekspresi subunit rantai respirasi mitokondrial (Forgacs et al., 2012) dan diduga bahwa mitokondria merupakan target pertama dan juga berperan sebagai efektor pada kasus toksisitas TCDD (Simões et al., 2010). Beberapa kerusakan pada sistem reproduksi jantan juga dipengaruhi oleh adanya deregulasi mitokondrial. TCDD menyebabkan stress oksidatif pada epididymis, testis, sel sertoli dan sperma (Latchoumycandane et al., 2003). Paparan TCDD pada sperma mencit secara akut menyebabkan hilangnya MMP yang disebabkan oleh tingginya kadar ROS (Fisher et al., 2005). Seiring dengan fungsi fisiologis mitokondria yang rusak, TCDD akan upregulation ekspresi BAX dan p53 pada testis tikus (Jin et al., 2010). Penelitian terdahulu melaporkan bahwa aktivitas enzim antioksidan menurun dan kadar hydrogen peroxide serta peroksidasi lipid meningkat pada testis, epididimis dan sperma tikus yang diberi paparan lindane. Senyawa TCDD menginduksi stress oksidatif melalui peningkatan peroksidasi lipid di mitokondria dan fraksi mikrosomal dari testis serta sperma tikus (Latchoumycandane et al., 2001).

Radikal bebas/ROS yang dibentuk di testis dalam kondisi fisiologis akan diikat secara efektif oleh sistem pertahanan antioksidan (Latchoumycandane and Mathur, 2002). 
Secara alami antioksidan telah terjadi secara ekstensif memiliki kapasitas melindungi organisme dan sel dari kerusakan yang memicu kejadian stress oksidatif. Antioksidan dapat menetralisasi radikal bebas dalam tubuh dengan cara memberikan satu elektronnya sehingga terbentuk molekul yang stabil dan mengakhiri reaksi radikal bebas (Cozzi et al., 1997).

Apoptosis pada sel spermatogenik dilihat menggunakan Tunnel Assay untuk melihat adanya apoptosis pada sel. Berdasarkan hasil perhitungan uji Kruskal Wallis terdapat perbedaan antar setiap kelompok perlakuan dan kemudian diuji dengan Mann Whitney untuk melihat perbedaan di antara kelompok perlakuan. Peningkatan apoptosis menunjukkan adanya gangguan pada sistem reproduksi jantan. Hal ini terlihat pada kelompok kontrol positif yang menunjukkan perbedaan yang nyata jika dibandingkan dengan kelompok kontrol negatif. Senyawa TCDD dapat menginduksi peningkatan ROS sehingga akan mengakibatkan peningkatan peroksidasi lipid, penurunan asam lemak jenuh dan meningkatan kadar asam lemak tak jenuh pada membran. Sehingga keadaan ini dapat meningkatkan kejadian apoptosis. Hal ini sejalan dengan penelitian Chen et al., 2010 yang mengatakan bahwa TCDD dapat mengaktivasi jalur intrinsik dan ekstrinsik apoptosis. Penelitian ini juga didukung oleh Durgesh et al, 2017 yang menyatakan bahwa TCDD menginduksi apoptosis pada sel HaCat 24 jam setelah pemberiannya dan pengamatan dilakukan melalui metode Annexin V. Lebih lanjutnya Durgesh juga menyatakan bahwa AhR memegang peran penting pada apoptosis yang terjadi di sel granul serebral yang disebabkan oleh TCDD seperti yang ditunjukkan di sel neuron kultur dari mencit AhR KO. Mencit tersebut tidak menunjukkan adanya apoptosis yang signifikan setelah paparan TCDD secara akut (Sánchez-Martin et al., 2011). Camacho et al., 2005 menunjukkan peran AhR dalam menginduksi apoptosis di sel $\mathrm{T}$ di timus dan menunjukkan bahwa AhR meregulasi FasL dan NFKB pada sel stromal, yang memegang peran penting dalam inisiasi apoptosis sel T.

Senyawa TCDD akan menyebabkan tingginya tingkat kematian sel, dan diketahui bahwa stress oksidatif dapat menyababkan kerusakan DNA (Bock and Köhle, 2005). Senyawa TCDD menginduksi apoptosis melalui berbagai mekanisme yang berbeda seperti pembentukan ROS, downregulation c-FLIP, aktivasi jalur MAPK, dan perusakan homeostasis kalsium (Yang and Lee, 2010; Singh et al., 2008; Morales-Hernández et al., 2012).

Tingkat apoptosis yang tinggi pada kelompok kontrol positif ditunjukkan sebagai warna kecokelatan yang disebabkan oleh paparan TCDD. Kelompok P3 yang diberikan antioksidan dengan dosis tertinggi menunjukkan perbedaan yang nyata dengan kelompok kontrol positif, namun tidak menunjukkan perbedaan yang nyata dengan kelompok P2. Hal ini karena rentang dosis antara kelompok P2 dan P3 tidak berbeda jauh, namun jika dibandingkan dengan kelompok P1 terlihat bahwa dosis kelompok P2 dan P3 lebih berpengaruh dalam menurunkan apoptosis. Hal ini menunjukkan bahwa kandungan antioksidan pada rumput kebar mampu menurunkan apoptosis. Kandungan antioksidan dalam rumput kebar cukup baik dalam mengikat ROS sehingga dapat menurunkan apoptosis.

Tubulus seminiferus memiliki germ cell dalam berbagai fase dan berasosiasi dengan sel sertoli. Membran basalis dan sel mioid mengelilingi tubulus seminiferus dan sel leydig serta pembuluh darah berada di interstitial. Spermatogonium dan sel sertoli 
menempel pada membran basalis (Nishimura dan Hernault, 2017).

Organisme umumnya terdiri dari dua garis keturunan yaitu somatic cells dan germ cells. Spermatogenesis adalah sebuah proses kompleks dari proliferasi dan diferensiasi germ cell. Spermatogenesis melibatkan differensiasi dari spermatogonium menjadi spermatosit melalui divisi sel mitosis dan produksi spermatid haploid dari spermatosit primer tetraploid melalui divisi sel miosis. Spermatid berubah menjadi spermatozoa pada fase final dari spermatogenesis. Proses ini dinamakan dengan spermiogenesis. Pada testis mencit, germ cell akan berdiferensiasi menjadi spermatozoa matang di dalam tubulus seminiferus. Pada saat spermatogonia tipe A mengalami divisi mitosis untuk berdiferensiasi dari tipe $A_{1}$ menjadi tipe $\mathrm{A}_{4}$. Beberapa sel tipe $\mathrm{A}_{4}$ akan berdiferensiasi menjadi spermatogonium intermediate, yang kemudian akan membelah dan membentuk spermatogonium tipe B. Spermatosit primer tetraploid terbnetuk dari sel tipe B melalui satu divisi mitosis dan kemudian mengalami miosis I dan menghasilkan spermatosit sekunder yang bersifat diploid. Setelah terjadinya miosis II, dua spermatid haploid masing-masing terbentuk dari dua spermatosit sekunder. Selama proses pembelahan dan maturasi spermatogonium tipe A menjadi spermatid, germ cell akan mengalami migrasi dari membran basalis menuju bagian lumen dari tubulus seminiferus. Selanjutnya spermatid mengalami transformasi menjadi spermatozoa melalui proses spermiogenesis yang melibatkan kondensasi dan elongasi nucleus, biogenesis akrosom dan pembentukan flagella. Spermiogenesis juga melibatkan peletakan konstituen seluler dari spermatid menjadi spermatozoon fungsional (seperti ribosom) ke dalam sitoplasmik droplet yang merupakan residu badan ketika spermatid menuju bagian lumen tubulus seminiferus. Hasilnya adalah spermatozoa matang yang dilepaskan ke dalam lumen (Nishimura dan Hernault, 2017).

Banyak faktor yang dapat mempengaruhi spermatogenesis termasuk perubahan patologis epitel pada tubulus seminiferus, merusak ekspresi gen, dan faktor lingkungan (Beissbarth et al., 2003). Studi terdahulu menunjukkan bahwa perubahan patologis pada epitel seminiferus mengakibatkan kerusakan pada sel sertoli dan germ cell yang menyebabkan terganggunya proses spermatogenesis (Vernet et al., 2006).

Pada preparat testis dengan pewarnaan HE kelompok kontrol positif menunjukkan penurunan gambaran histopatologis menurut Johnsen score jika dibandingkan dengan kelompok kontrol negatif. Hal ini dikarenakan adanya beberapa perubahan di antaranya kerusakan epitel tubulus seminiferus, perubahan epitel basalis dan pengurangan jumlah spermatozoa. Hal ini disebabkan oleh paparan TCDD sehingga sel spermatogenik banyak yang mengalami kematian sel.

\section{KESIMPULAN}

Kesimpulan dari penelitian ini adalah pemberian ekstrak rumput kebar pada mencit jantan setelah dipapar TCDD memiliki apoptosis sel spermatogenik yang lebih rendah dan gambaran histopatologis sel spermatogenik yang lebih baik pada Johnsen Score jika dibandingkan dengan kelompok yang hanya mendapatkan paparan TCDD. Dosis ekstrak rumput kebar $0,135 \mathrm{mg} / \mathrm{gBB} /$ hari merupakan dosis paling efektif dalam menurunkan apoptosis dan memperbaiki gambaran histopatologis sel spermatogenik pada mencit jantan yang dipapar TCDD. 


\section{DAFTAR PUSTAKA}

Aylward, L.L., R.C. Brunet., G. Carrier., S.M. Hays., C.A. Cushing., L.L. Needham., D.G. Patterson., P.M. Gerthoux., P. Brambilla and P. Mocarelli. 2004. Concentrationdependent TCDD elimination kinetics in humans: toxicokinetic modeling for moderately to highly exposed adults from Seveso, Italy, and Vienna, Austria, and impact on dose estimates for the NIOSH cohort expo Anal Environ Epidemiol. 15: 51-65.

Beissbarth, T., I. Borisevich and A. Hörlein. 2003. Analysis Of CREMDependent Gene Expression During Mouse Spermatogenesis. Mol Cell Endocrinol 212: 29-39.

Bock, K.W. and C. Köhle. 2005. Ah receptor- and TCDD-Mediated Liver Tumor Promotion: Clonal Selection and Expansion of Cells Evading Growth Arrest and Apoptosis. Biochem Pharmaco. 69: 1403-1408.

Chen, S.C., T.L. Liao., Y.H. Wei., C.R. Tzeng and S.H. Kao. 2010. Endocrine disruptor, dioxin (TCDD)-induced Mitochondrial Dysfunction and Apoptosis in Human Trophoblast-like JAR Cells. Mol Hum Reprod. 16 (5): 361-372.

Christijanti, W., N.R. Utami dan A. Iswara. 2010. Pemberian Antioksidan Vitamin C dan E terhadap Kualitas Spermatozoa Tikus Putih Terpapar Allethrin. Biosaintifika. 2(1): 18-26.
Dhanabalan, S. and P.P. Mathur. 2009. Low Dose of 2,3,7,8, Tetrachlorodibenzo-p-dioxin Induces Testicular Oxidative Stress In Adult Rats Under The Influences of Corticosterone. Exp. Toxicol. Patho. 61: 415-423.

Enan, E., F. El-Sabeawy., J. Overstreet., F. Matsumura and B. Lasley. 1998. Mechanisms ofgender-specific TCDD-induced toxicity in guinea pig adipose tissue, Reprod.Toxicol. 12: 357-369.

EPA (Environmental Protection Agency). 2012. Recommended guidelines for humanexposure to $\mathrm{CDD}, \mathrm{CDF}$, and PCB congeners. properties, environmental levels, and background exposures, in: Exposure and Human Health Reassessment of 2,3,7,8Tetrachlorodibenzo-p-Dioxin (TCDD) and Related Compounds: National Academy of Sciences (NAS) Review Draft, National Center for Environmental Assessment. United States. 2004. 4-146.

Faqi, A.S., P.R. Dalsenter., H.J. Merker and I. Chahoud. 1998. Reproductive toxicity and tissue concentrations of low doses of 2,3,7,8-tetrachlorodibenzo-pdioxin inmale offspring rats exposed throughout pregnancy and lactation. Toxicol.Appl. Pharmacol. 150: 383-392.

Fisher, M.T., M. Nagarkatti and P.S. Nagarkatti. $2005 . \quad$ Aryl Hydrocarbon Receptor-dependent Induction of Loss Mitochondrial Membrane Potential in Epididymal Spermatozoa by 2,3,7,8-tetrachlorodibenzo-pdioxin (TCDD). Toxicol Lett. 157(2): 99-107. 
Forgacs, A.L., M.N. Kent., M.K. Makley., B. Mets., N. DelRaso., G.L. Jahns., L.D. Burgoon., T.R. Zacharewski and N.V. Reo. 2012. Comparative Metabolomic and Genomic Analyses of TCDD-Elicited Metabolic Disruption in Mouse and Rat Liver. Toxicol Sci. 125 (1): 41-55.

Gies, A., G. Neumeier., M. Rappolder and R. Konietzka. 2007. Risk assessment of dioxins and dioxinlike PCBs in food - comments by the German Federal Environmental Agency. Chemosphere. 67: 344-349.

Gray, L.e., J.S. Ostby and W.R. Kelce. 1997. A dose response analysis of the reproductive effects of a single gestational dose of 2,3,7,8 tetrachlorodibenzo-p-dioxin in male long evans hooded rat offspring. Toxicol Appl Pharmacol. 146: 11-20.

Guo, Y.L., P.C. Hsu., C.C. Hsu and G.H. Lambert. 2004. Semen quality after prenatal exposure to polychlorinated biphenyls and dibenzofurans. Lancet. 356: 12401241.

Inngjerdingen, M., K.T. Inngjerdingen, T.R. Patel., S. Allen., X. Chen., B. Rolstad., G.A. Morris., S.E. Harding., T.E. Michaelsen., D. Diallo and B.S. Paulsen. 2008. Pectic Polysaccharides from Biophytum petersianum Klotzsch, and Their Activation of Macrophages and Dendritic Cells. Glycobiology. 18(12): 1074-1084.
Jin, M.H., C.H. Hong., H.Y. Lee., H.J. Kang and S.W. Han. 2010. Toxic Effects of Lactational Exposure to 2,3,7,8-tetrachlorodibenzo-pdioxin (TCDD) on Development of Male Reproductive System: Involvement of Antioxidants, Oxidant, and p53 Protein. Environ. Toxicol. 25(1): 1-8.

Jong, S.C., Il, W.K., Seock, Y.H., Bong, J.S., and Si, K.K. 2007. Effect of 2,3,7,8-tetrachlorodibenzo- $p$-dioxin on testicular spermatogenesisrelated panels and serum sex hormone levels in rats. Journal Compilation $2007 \quad$ BJU International 101: 250 - 255.

Latchoumycandane, C., K.C. Chitra and P.P. Mathur. 2003. 2,3,7,8, Tetrachlorodibenzo-p-dioxin (TCDD) Induces Oxidative Stress in The Epididymis and Epididymal Sperm of Adult Rats. Arch. Toxicol. 77(5): 280-284.

Mendiola, J., A.M. Torres-Cantero and A. Agarwal. 2009. Lifestyle factors and male fertility: an evidencebased review. Arch Med Sci. 5: 312.

Morales-Hernández, A., F.J. SánchezMartín., M.P. Hortigón-Vinagre., F. Henao and J.M. Merino. 2012. 2,3,7,8-Tetrachlorodibenzo-pdioxin induces Apoptosis by Disruption of Intracellular Calcium Homeostasis in Human Neuronal Cell Line SHSY5Y. Apoptosis. 184 (17): 1170-1181.

Nishimura, H. and S.W.L. Hernault. Primer Spermatogenesis. 2017. Current Biology. 27: 979-1001. 
Nowak, M., J.A. Madej and P. Dziegeil. 2007. Intensity of Cox 2 Expression in Cell of Soft Tissue Fibrosarcomas in Dog As Related to Grade of Tumor malignation. Bull. Vet. inst. Pulawy. 51: 275-279.

Pereira, S.P., G.C. Pereira., A.J. Moreno and P.J. Oliveira. 2009. Can Drug Safety Be Predicted and Animal Experiments Reduced by Using Isolated Mitochondrial Fractions. Altern. Lab. Anim. 37(4): 355-365.

Pilsner, J.R., M. Parker., O. Sergeyev and A. Suvorov. 2017. Spermatogenesis disruption by dioxins: Epigenetic reprograming and windows of susceptibility. Repro Toxicol. 69: 221-229.

Sadsoeitoeboen, P.D. 2005. Manfaat Ekstrak Rumput Kebar (Biophytum petersianum Klotzsch) terhadap Penampilan Reproduksi Mencit Putih Betina. Institut Pertanian Bogor. Bogor. 30-43.

Shertzer, H.G., M.B. Genter., D. Shen., D.W. Nebert., Y. Chen and T.P. Dalton. 2006. TCDD Decreases ATP Levels and Increase Reactive Oxygen Production Through Changes in Mitochondrial $\mathrm{F}(0) \mathrm{F}(1)$-ATP Synthase and Ubiquinone. Toxicol Appl Pharmacol. 213(3): 363-374.

Shibamoto, T., A. Yasuhara and T. Katami. 2007. Dioxin formation from waste incineration. Rev Environ Contam Toxicol. 190: 141.
Singh, N.P., M. Nagarkatti and P. Nagarkatti. 2008. Primary peripheral $\mathrm{T}$ Cells Become Susceptible to 2,3,7,8tetrachlorodibenzo-p-dioxinmediated Apoptosis In Vitro upon Activation and in The Presence of Dendritic Cells. Mol. Pharmacol. 73: 1722-1735.

Sonne, C., K. Gustavon., F.F. Riget., R. Dietz., M. Birkved and R.J. Letcher. 2009. Reproductive performance in East Greenland Polar Bears (Ursus maritimus) may be affected by organohalogen contaminants as shown by physiogically-based pharmacokinetic (PBPK) modeling. Chemosphere. 77(11): 1558-1568.

Srinivasan, G.V., V.K. Krishnan and R. Subban. 2017. A New Flavonoid Diglycoside from Biophytum reindwardtii (Zucc.) Klotzsch. and Evaluation of Its Antioxidant and Anticancer Activities. Indian J. Chem. 56(2): 880-889.

Takeda, T., M. Fujii., Y. Hattori., M. Yamamoto., T. Shimazoe., Y. Ishii., M. Himeno and H. Yamada. 2014. Maternal exposure to dioxin imprints sexual immaturity of the pups through fixing the status of the reduced expression of hypothalamic gonadotropin releasing hormone. Mol. Pharmacol. 85: 74-82. 
Vernet, N., C. Dennefeld, F. Guillou andw P. Chambon. 2006. Prepubertal Testis Development Relies On Retinoic Acid but Not Rexinoid Receptors In Sertoli Cells. EMBO J. 25: 5816-5825.

Widholm, J.J., B.W. Seo., B.J. Strupp., R.F. Seegal and S.L. Schantz. 2003. Effects of perinatal exposure to 2,3,7,8-tetrachlorodibenzo-pdioxin on spatial and visual reversal learning in rats. Neurotoxicol Teratol. 25: 459-471
Wormley, D.D., A. Ramesh and D.B. Hood. 2004. Environmental contaminant-mixture effects on CNS development, plasticity, and behavior. Toxicol Appl Pharmacol. 197: 49-65.

Yang, J.H. and H.G. Lee. 2010. 2,3,7,8Tetrachlorodienzo-p-dioxin Induces Apptosis of Articular Chondrocytes in Culture. Chemosphere. 79: 278-284.

Zaidi, Z.F. 2010. Gender differences in human brain: a review. Open Anatomy J. 2:37-55. 